\title{
ANALISIS PENERAPAN WITHHOLDING TAX SYSTEM PRESPEKTIF MUTATIS MUTANDIS PADA LEMBAGA KEUANGAN SYARIAH (Studi Kasus pada BMT Al-Hijrah KAN Jabung)
}

\author{
Siti Eli Kurniawati \\ Jurusan Akuntansi Program Studi Akuntansi \\ Universitas Islam Negeri Maulana Malik Ibrahim Malang \\ Email: elikurniawati18@gmail.com
}

\begin{abstract}
The research objective is to know the tax cut by sharia financial institution by referring to the Tax Legislation on Income Tax $(\mathrm{PPh})$ that is generally applicable, as well as the procedures of tax cuts using the means of Withholding Tax System and the basic of tax imposition on revenue sharing in sharia financial institution.The data analyzing method used by the researcher is qualitative data analysis with Case Study formulate theory, looking at theory as well as cases as the induction process from the observation toward facts (gathering information). Based on the data analysis and interview result done in this research, the finding suggests that BMT Al Hijrah KAN Jabung have implemented tax system in accordance with the generally applicable tax provision as well as withholding tax system in BMT Al Hijrah KAN Jabung which is implemented in deposit revenue sharing and time mudharabah (deposito).
\end{abstract}

Key Word: Withholding Tax System, Tax, Cut, Revenue Sharing.

\begin{abstract}
Abstrak
Tujuan dari penelitian ini adalah untuk mengetahui pajak yang dipotong oleh lembaga keuangan syariah dengan mengacu pada Undang-undang perpajakan tentang Pajak Penghasilan $(\mathrm{PPh})$ yang berlaku umum, serta tatacara memotongan Pajak dengan menggunakan Withholding Tax System dan dasar pengenaan pajak atas bagi hasil di lembaga keuangan syariah. Metode analisis data yang digunakan penulis adalah metode analisis data kualitatif dengan Case Study menyusun teori, memandang teori serta kasus sebagai hasil proses induksi dari pengamatan terhadap fakta (pengumpulan informasi). Berdasarkan analisis data dan hasil wawancara yang telah dilakukan dalam penelitian ini, ditemukan bahwa BMT Al Hijrah KAN Jabung telah melakukan sistem perpajakan sesuai dengan ketentuan perpajakan yang berlaku umum serta withholding tax system pada BMT Al Hijrah KAN Jabung terdapat pada bagi hasil simpanan dan mudharabah berjangka (deposito).
\end{abstract}

Kata Kunci : Withholding Tax System, Pajak, Pemotongan, Bagi Hasil 


\section{PENDAHULUAN}

Pemerintah Indonesia saat ini sedang melakukan kebijakan-bebijakan fiskalnya. Sehingga hal tersebut mampu mempercepat pembangunan ekonomi Indonesia yang telah direncanakan. Salah satunya yaitu pertumbuhan ekonomi dan fundamental makro ekonomi yang kuat membuat peringkat Indonesia dalam Global Competitiveness Report 2017-2018 menapak ke peringkat 36 dari semula peringkat 41 (naik 14 peringkat dari posisi lima tahun lalu). Beberapa perbaikan yaitu 10 dari 12 kategori, termasuk kesehatan, pendidikan dasar, dan infrastruktur. Perkembangan ekonomi tersebut didukung perkembangan Realisasi APBN 2017 yakni Pendapatan Negara mencapai Rp. 1.099,3 triliun (63,3 persen terhadap APBN) lebih baik dibandingkan yang sama tahun sebelumnya yang hanya mencapai Rp. 1.082,6 triliun (60,6 persen terhadap APBNP) (Kemenkue, 2017).

Untuk menutupi belanja negara yang sangat besar, pemerintah harus lebih mengoptimalkan penerimaan pajak yang salah satunya dengan menggunakan sistem pemungutan pajak. Dalam peraturan perpajakan, Indonesia mengenal tiga sistem pemungutan pajak yaitu official assesmsment system, self assessment system, dan withholding tax system. Menurut Leornado (2016), cara yang paling mudah dilakukan oleh pemerintah untuk memungut pajak adalah dengan cara mewajibkan wajib pajak untuk melakukan pemungutan dan pemotongan atas pajaknya pihak lain. Cara seperti ini dikenal dengan nama withholding tax system yang memberikan wewenang kepada pihak ketiga untuk memotong besarnya pajak terutang oleh wajib pajak, dimana didalam UU No. 36 Tahun 2008 juga telah dijelaskan bahwa pihak ketiga dimaksud adalah lembaga yang berbadan hukum. Dengan cara ini, pemerintah akan dengan mudah untuk mengumpulkan pajak tanpa memerlukan upaya dan biaya besar.

Hadirnya BMT diharapkan mampu menjadi sarana dalam menyalurkan dana untuk usaha bisnis kecil dengan mudah dan bersih, dengan disadarkan pada kemudahan dan bebas riba/bunga, memperbaiki/meningkatkan taraf hidup masyarakat bawah, lembaga keuangan alternatif yang mudah diakses oleh masyarakat bawah dan bebas riba/bunga, lembaga untuk memberdayakan ekonomi umat, mengentaskan kemiskinan, meningkatkan produktivitas. Seperti halnya BMT Al Hijrah KAN Jabung yang mempunyai potensi yang cukup tinggi karena selain didukung oleh kondisi masyarakat sekitar juga mempunyai kualitas SDM yang memadai. BMT Al Hijrah KAN Jabung yang berada di tengah desa menjadikan salah satu fasilisator masyarakat dalam hal menabung maupun pembiayaan. Selain itu, dengan adanya prinsip syariah yang diterapkan oleh BMT Al Hijrah KAN Jabung yang menjadikan suatu pandangan masyarakat bahwa BMT merupakan salah satu lembaga keuangan yang terbebas dari bunga menjadikan BMT sebagai salah satu pilihan masyarakat dalam menentukan sarana transaksi syariah. 
Dalam Peraturan mengenai penghasilan, biaya, dan pemotongan pajak atau pemungutan pajak dari usaha perbankan syariah berlaku mutatis mutandis ketentuan dalam Undang-undang Nomor 36 Tahun 2008 tentang Pajak Penghasilan. Menteri keuangan juga mengatur dalam PMK Nomor 136/PMK.03/2011 yang menjelaskan bahwa penghasilan dengan nama dan dalam bentuk apapun yang diterima atau diperoleh perbankan syariah termasuk bonus, bagi hasil, margin keuntungan yang diterima dari kegiatan/transaksi nasabah penerima fasilitas merupakan objek PPh sesuai ketentuan pengenaan PPh atas bunga. Maksud dari mutatis mutandis adalah ketentuan-ketentuan mengenai penghasilan, biaya, dan pemotongan pajak atau pemungutan pajak yang berlaku dalam Undang-undang PPh berlaku pula diperaturan Menkeu.

\section{TINJAUAN PUSTAKA}

\section{Pengertian Pajak}

Menurut Rochmat Soemitro pajak adalah iuran kepada kas negara berdasarkan Undang-undang (yang dapat dipaksakan) dengan tidak mendapat jasa timbal (kontraprestasi), yang langsung dapat ditunjukkan dan digunakan untuk membayar pengeluaran umum (Mardiasmo, 2016). Menurut S.I.Djajadiningrat pajak adalah sebagai suatu kewajiban menyerahkan sebagian dari kekayaan ke kas negara yang disebabkan suatu keadaan, kejadian, dan perbuatan yang memberikan kedudukan tertentu, tetapi bukan sebagai hukuman, menurut peraturan yang ditetapkan pemerintah serta dapat dipaksakan, tetapi tidak ada jasa timbal balik dari negara secara langsung untuk memelihara kesejahteraan secara umum. Dr. N. J. Feldmann mengemukakan pajak adalah prestasi yang dipaksakan sepihak oleh dan terutang kepada penguasa (menurut norma-norma yang ditetapkannya secara umum), tanpa adanya kontraprestasi, dan semata-mata digunakan untuk menutup pengeluaranpengeluaran umum (Resmi, 2017). Menurut Undang-Undang No. 28 Tahun 2007 tentang Ketentuan Umum dan Tata Cara Perpajakan, Pajak adalah kontribusi wajib kepada negara yang terutang oleh orang pribadi atau badan yang bersifat memaksa berdasarkan Undang-Undang, dengan tidak mendapatkan imbalan secara langsung dan digunakan untuk keperluan negara bagi sebesar-besarnya kemakmuran rakyat.

\section{Sistem Pemungutan Pajak}

Dalam pemungutan pajak dikenal beberapa sistem pemungutan, yaitu:

\section{Official Assessment System}

Adalah suatu sistem pemungutan yang memberi wewenang kepada pemerintah (fiskus) untuk menentukan besarnya pajak yang terutang oleh Wajib Pajak. 


\section{Ciri-cirinya:}

a) Wewenang untuk menentukan besarnya pajak terutang ada pada fiskus

b) Wajib pajak bersifat pasif

c) Utang pajak timbul setelah dikeluarkan surat ketetapan pajak oleh fiscus

\section{Self Assessment System}

Adalah suatu sistem pemungutan pajak yang memberi wewenang kepada Wajib Pajak untuk menentukan sendiri besarnya pajak yang terutang.

Ciri-cirinya:

a) Wewenang untuk menentukan besarnya pajak terutang ada pada wajib pajak sendiri.

b) Wajib pajak aktif, mulai dari menghitung, menyetor dan melaporkan sendiri pajak yang terutang.

c) Fiskus tidak ikut campur dan hanya mengawasi.

\section{Withholding System}

Adalah suatu sistem pemungutan pajak yang memberi wewenang kepada pihak ketiga (bukan fiskus dan bukan Wajib Pajak yang bersangkutan) untuk memotong atau memungut pajak yang terutang oleh wajib pajak. Penunjukan pihak ketiga ini dilakukan sesuai peraturan perundang-undangan perpajakan, keputusan presiden, dan peraturan lainnya untuk memotong serta memungut pajak, menyetor pajak, dan mempertanggungjawabkan melalui sarana sarana perpajakan yang tersedia. Berhasil atau tidaknya pelaksanaan pemungutan pajak banyak bergantung pada pihak ketiga yang ditunjuk.

Ciri-cirinya: wewenang memotong atau memungut pajak yang terutang pada pihak ketiga, yaitu pihak selain fiskus dan Wajib Pajak.

\section{Withholding Tax System}

Withholding tax system adalah suatu sistem pemungutan pajak yang memberi wewenang kepada pihak ketiga (bukan fiskus dan bukan Wajib Pajak yang bersangkutan) untuk memotong atau memungut pajak yang terutang oleh Wajib Pajak (Mardiasmo, 2016). Ide pemungutan pajak menggunakan cara withholding tax system pertama kali diintroduksi (dikenalkan) di Amerika Serikat pada tahun 1943 dalam rangka mengakselerassi pemotongan/pemungutan pajak selama perang dunia II. Karena terbukti effisien dan efektif, withholding tax system dengan cepat diadopsi oleh negara-negara lainnya. Dalam withholding tax system, pihak ke-3 (yang berkaitan dengan wajib pajak) yang menghitung, menetapkan, menyetorkan, dan melaporkan pajak yang sudah dipungut/dipotong tersebut. Misalanya, pemberi kerja wajib menghitung dan menetapkan berapa pajak penghasilan yang harus dipotong atas penghasilan (gaji, upah, dan sebagainya) yang diterima oleh pegawainya. Lalu ia 
juga harus menyetorkan pajak penghasilan yang telah dipotong tersebut, kemudian melaporkannya kepada Kantor Pelayanan Pajak (Annisa, 2016).

Seperti telah disebutkan di atas, withholding tax system ini merupakan cara termudah bagi pemerintah untuk memungut pajak, tetapi di pihak lain, yaitu pihak wajib pajak, withholding tax system ini menimbulkan cost of compliance (beban pemenuhan kewajiban) perpajakan yang tinggi, yaitu misalnya beban administrasi, beban sanksi administrasi kalau terlambat memotong dan/atau menyetorkan, atau tidak dan/atau belum memotong pajaknya pihak lain. Dengan kata lain, dalam sistem withholding tax system ini, Wajib Pajak diwajibkan untuk memungut dan memenuhi administrasi pajaknya pihak lain (wajib pajak lain) yang mana kewajiban untuk memenuhi administrasi pajaknya pihak lain tersebut sebenarnya adalah tanggung jawab pemerintah (dalam hal ini adalah Ditjen Pajak). Apabila dikaitkan dengan self assessment system, yang memberikan kepercayaan penuh kepada Wajib Pajak untuk menghitung, memperhitungkan, membayar, dan melaporkan kewajiban perpajakannya (kewajiban pajak wajib pajak sendiri, bukan pajaknya wajib pajak lain/pihak lain), maka konsep withholding tax system ini berbeda dengan self assessment system. Dalam withholding tax system, Wajib Pajak diberi kewajiban untuk memotong, menyetorkan,dan mengadministrasikan pajaknya pihak lain. Sedangkan dalam self assessment system, Wajib Pajak berkewajiban untuk menghitung, menyetorkan, dan mengadministrasikan kewajiban pajaknya sendiri.

\section{Lembaga Keuangan Syariah di Indonesia}

Lembaga keuangan syariah di Indonesia khususnya perbankan syariah mulai berkembang dengan pesat sejak tahun 1999 yaitu setelah berlakunya Undang-undang nomor 10 tahun 1998 yang merupakan penyempurnaan dari Undang-undang nomor 7 tahun 1992 tentang perbankan. Dengan berkembangnya perbankan syariah di Indonesia tersebut mendorong perkembangan lembaga keuangan syariah lainnya seperti halnya Asuransi Syariah, Lembaga Pembiayaan Syariah, Pegadaian Syariah, Koperasi Syariah dan juga Lembaga Keuangan Mikro Syariah yang sering disebut dengan Baitul Mall wat Tamwil (BMT) yaitu lembaga keuangan mikro yang berbadan hukum Koperasi Syariah atau Koperasi Jasa Keuangan Syariah (Wiroso, 2011).

Dalam UU No. 21 Tahun 2008, menjelaskah bahwa Perbankan Syariah adalah segala sesuatu yang menyangkut tentang Bank Syariah dan Unit Usaha Syariah, mencakup kelembagaan, kegiatan usaha, serta cara dan proses dalam melaksanakan kegiatan usahanya. Alasan mendasar lahirnya bank syariah sebenarnya lebih berkaitan dengan masalah keyakinan berupa unsur riba, ketidak adilan dan moralitas dalam melakukan usaha. Penerapan bunga sebagai landasan operasional perbankan yang ada sebelumnya (bank konvensional) dianggap sebagai bentuk 
transaksi riba yang dalam agama Islam jelas-jelas dilarang. Bunga diyakini mengandung unsur riba karena dalam sistem bunga terdapat unsur ketidakadilan karena pemilik dana mewajibkan peminjam dana untuk membayar lebih dari pada yang dipinjam tanpa memperhatikan apakah peminjam mengalami keuntungan atau kerugian. Sebagaimana yang telah dijelaskan dalam Al-Quran surah An Nisa' ayat 58.

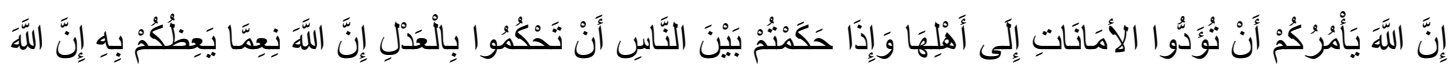
كَانَ سَمِيعًا بَصِيرًا

"Sesungguhnya Allah menyuruh kamu menyampaikan amanah kepada yang berhak menerimanya, dan (menyuruh kamu) apabila menetapkan hukum di antara manusia supaya kamu menetapkan dengan adil. Sesungguhnya Allah memberi pengajaran yang sebaik-baiknya kepadamu. Sesungguhnya Allah adalah Maha mendengar lagi Maha Melihat.” (QS. An-Nisa': 58).

\section{Baitul Maal wal Tamwil (BMT)}

Kemunculan lembaga Baitul Maal wal Tamwil, yang melakukan kegiatannya berdasarkan prinsip-prinsip syariah yang dirasakan dapat memenuhi kebutuhan, tidak hanya karena sistemnya yang syariah, namun juga fungsi manfaat sosial dan ekonomis. Oleh karena itu, kemudian bermunculan lembaga-lembaga keuangan mikro syariah dengan nama genetik BMT. Sampai dengan tahun 1993, kegiatan operasional BMT di Indonesia masih beragam, baik dari sisi produk, akad, maupun sistem operasionalnya. Situasi perekonomian nasional yang krisis pada tahun 1991, melatarbelakangi kebijakan pemerintah yang dikenal dengan “Tight Money Policy”, yang disusul dengan kebijakan perbankan dengan mempermudah pendirian bankbank. Pada masa inilah BMT yang beroperasi di Indonesia mendasarkan kegiatan operasionalnya sebagai sebuah lembaga keuangan dengan prinsip sistem perbankan syariah, yang kemudian diadopsi dan dilegalkan oleh pemerintah melalui Departemen Koperasi dan UMKM sebagai departemen terkait dengan Keputusan Menteri Keuangan UMKM No. 91/Kep/M.KUKM/IX/2004 (Cokrohadisumarto, Ismail, Wibowo, 2016).

\section{Mutatis mutandis}

Mutatis mutandis berasal dari bahasa latin yang artinya kurang lebih perubahan yang penting telah dilakukan. Istilah ini digunakan pada saat membandingkan dua situasi dengan variabel yang berbeda. Menurut Black's Law Dictionary Seventh Edition, mutatis mutandis berarti:

"All necessary changes having been made. with the necessary changes, what was said regarding the first contract applies mutatis mutandis to all the later ones." (Semua perubahan yang diperlukan telah dibuat. dengan perubahan yang diperlukan, 
apa yang dikatakan tentang kontrak pertama berlaku mutatis mutandis untuk semua yang kemudian).

Sedangkan menurut buku Terminologi Hukum karangan IPM Ranuhandoko, mutatis mutandis berarti "dengan perubahan yang perlu-perlu". Sebagaimana dalam beberapa Undang-undang yang berlaku mutatis mutandis seperti berikut:

a) Pasal 54 ayat (3) UU No. 40 Tahun 2007 (UUPT):

"Ketentuan sebagaimana dimaksud dalam Pasal 52 ayat (4) dan ayat (5) mutatis mutandis berlaku bagi pemegang pecahan nilai nominal saham."

Merujuk pada pengertian mutatis mutandis di atas, maksud dari pasal ini adalah bahwa ketentuan pada pasal 52 UUPT, dengan perubahan- perubahan yang diperlukan, berlaku juga untuk pemegang pecahan nilai nominal saham.

b) Pasal 28 ayat 1 UU No. 14 Tahun 2001 tentang Paten (UU Paten):

"Ketentuan sebagaimana dimaksud dalam Pasal 24 berlaku secara mutatis mutandis terhadap Permohonan yang menggunakan Hak Prioritas."

Maksudnya, ketentuan sebagaimana diatur dalam pasal 24 UU Paten tersebut (data apa saja yang diisikan pada permohonan untuk mendapatkan paten), berlaku juga, dengan perubahan-perubahan yang diperlukan, untuk permohonan paten yang menggunakan hak prioritas.

Dari uraian di atas, maka mutatis mutandis dapat diartikan dengan perubahanperubahan yang diperlukan atau penting. Hukum mutatis mutandis dalam islam sama halnya dengan qiyas. Qiyas menurut bahasa ialah pengukuran sesuatu dengan yang lainnya atau menyamakan sesuatu dengan sejenisnya. Sedangkan menurut terminologi, definisi qiyas secara umum adalah suatu proses penyingkapan kesamaan hukum suatu kasus yang tidak disebutkan dalam suatu nash baik di Al Quran dan As Sunnah dengan suatu hukum yang disebutkan dalam nash karena ada kesamaan dalam alasannya ('illat), (Syafi'I, 2007). Hal ini sesuai dengan (QS Al- Hashr:2).

" maka ambillah pelajaran wahai orang-orang yang mempunyai wawasan”. 


\section{METODE PENELITIAN}

\section{Jenis Penelitian}

Dalam penelitian ini pendekatan yang dilakukan adalah melelalui pendekatan kualitatif dengan metode Case Study untuk membangun analisa secara mendalam atas kasus tunggal atau multi-kasus.

\section{Lokasi Penelitian}

Lokasi penelitian ini dilakukan di salah satu lembaga keuangan syariah. Adapun objek penelitian yang diambil oleh penulis guna mendapatkan data adalah Baitul Maal wal Tamwil (BMT) Al Hijrah KAN Jabung yang bertempat di jalan Suropati No. 04, Kemantren, Jabung, Malang, Jawa Timur.

\section{Subjek Penelitian}

Subjek penelitian ini adalah pegawai lembaga keuangan syariah yang memiliki wewenang untuk melakukan witholding tax system. Dalam hal ini, subjek penelitian yang diambil penulis adalah salah satu pegawai di Baitul Maal wal Tamwil (BMT) Al Hijrah KAN Jabung.

\section{Data dan Jenis Data}

Untuk penulisan skripsi ini, data yang dibutuhkan adalah data primer dan sekunder. Data primer, yaitu sumber data penelitian yang diperoleh secara langsung dari pihak yang terkait dengan menggunakan sistem tanya jawab (wawancara) mengenai proses pemotongan/pemungutan serta perhitungannya. Data Sekunder, yaitu sumber data penelitian yang diperoleh secara tidak langsung melainkan melalui media perantara (diperoleh dan dicatat oleh pihak lain). Data sekunder yang dibutuhkan berupa bukti, catatan, atau laporan historis yang telah tersusun dalam arsip (data dokumenter) yang dipublikasikan dan yang tidak dipublikasikan.

\section{Teknik Pengumpulan Data}

Teknik pengumpulan data merupakan langkah yang paling utama dalam penelitian, karena tujuan utama dari penelitian adalah mendapatkan data. Sehingga untuk memaksimalkan hasil yang didapat, metode kualitatif pada teknik pengumpulan data memiliki bermacam-macam, antara lain: observasi (pengamatan), interview (wawancara), kuesioner (angket), dokumentasi, dan gabungan keempatnya (Sugiono:2012).

\section{Analisis Data}

Analisis data merupakan upaya mencari dan mendata secara sistematis catatan observasi, wawancara, dan lain-lainnya untuk meningkatkan pemahaman peneliti tentang kasus yang diteliti dan menyajikannya sebagai temuan bagi orang lain (Azizah, 2015).Penulisan skripsi ini menggunakan metode analisis data yang digunakan penulis adalah metode analisis data kualitatif dengan Case Studymenyusun 
teori, memandang teori serta kasus sebagai hasil proses induksi dari pengamatan terhadap fakta (pengumpulan informasi). Teori pada dasarnya merupakan kulminasi dari penelitian kualitatif yang disusun melalui proses pengumpulan data, kategorisasi data dan pengembangan pola atau susunan teori.

Beberapa hal yang perlu dianalisis dalam penelitian ini antara lain:

1. Mengetahui jenis withholding tax system yang dipotong/dipungut di BMT Al Hijrah KAN Jabung.

2. Menghitung witholding tax system atas penghasilan atas bagi hasil simpanan dan deposito perusahaan jasa keungan syariah sesuai dengan peraturan perpajakan dengan data yang diperoleh.

3. Membandingkan perhitungan hasil penelitian antara data yang diperoleh dari BMT Al Hijrah KAN Jabung dengan peraturan perpajakan yang berlaku umum.

4. Menganalisis apakah pehitungan, pemotongan/pemungutan dan pelaporan witholding tax system sudah sesuai atau belum dengan peraturan perpajakan yang ditetapkan di Undang-undang Perpajakn dengan perspektif mutatis mutandis.

\section{HASIL PENELITIAN}

\section{Hasil Penelitian}

Selain sebagai pembayar pajak, perusahaan juga sebagai pemotong pajak terhadap pihak ketiga. Dengan cara seperti ini pemerintah akan dengan mudah dapat mengumpulkan pajak tanpa upaya dan biaya yang besar. Biasanya withholdimg tax system ini berlaku pada peruasahaan atau badan usaha yang melakukan pemotongan atau pemungutan pajak atas penghasilan karyawan maupun pajak yang berasal dari bentuk usaha. BMT Al Hijrah merupakan salah satu unit di KAN Jabung yang bergerak dibidang jasa keuangan dan memberikan bagi hasil kepada nasabah tentunya melakukan beberapa pemungutan pajak dengan withholding tax system.

Dalam pelaksaannya, BMT Al Hijrah KAN Jabung hanya melakukan perhitungan dan pemotongan pajak atas bagi hasil dari simpanan dan mudharabah berjangka (deposito), selain hal itu pemotongan dan pemungutan atas pajak organisasi dan pajak usaha lainnya dilakukan oleh pihak KAN Jabung pusat yang khusus menangani keuangan dan perpajakan di KAN Jabung. Sesuai dengan pernyataan ibu Uswatun Hasanah selaku Kabag Technical Support BMT Al Hijrah KAN Jabung:

“KAN Jabung ini melakukan dan menghitung Pajak atas pendapatan, pajak atas gaji karyawan, pajak bagi hasil, dan pajak lainnya yang berhubungan dengan organisasi dan usaha, akan tetapi yang di hitung oleh BMT hanya pajak bagi hasil saja. Untuk yang lainnya dilakukan oleh bagian holding. Dan BMT hanya melakukan pemungutan pajak atas bagi hasil saja, yang membayar tetap holding dibagian keuangan”. 
Withholding tax system yang dilakukan oleh BMT Al Hijrah hanya sampai tahap pemungutan pajak bagi hasil saja, selebihnya BMT Al Hijah menyerahkan semuanya ke bidang keuangan pusat (holding) di bagian pajak yang bertanggung jawab atas semua jenis pajak yang harus dibayar dan dilaporkan. Dalam hal pembayaran dan pelaporan, sesuai dengan hasil wawancara tersebut bahwa BMT Al Hijrah KAN Jabung tidak ikut campur. Sebagai unit lembaga keuangan yang dimiki KAN Jabung, BMT hanya melakukan tugasnya dalam penerimaan dana dan penyaluran dana sehingga untuk proses withholding tax system tidak sepenuhnya dilakukan oleh BMT, melainkan pembagian tuga dengan bagian keuangan (holding).

Hasil pengamatan dan wawancara kepada beberapa karyawan di BMT AL Hijrah KAN Jabung mengenai withholding tax system hampir semua karyawan tidak mengetahui sistem pemungutan tersebut. Akan tetapi, setelah dijelaskan difinisi withholding tax system itu sendiri, ternyata BMT Al Hijrah KAN jabung sudah menerapkan sistem pemungutan tersebut. Hal ini sesuai dengan keterangan Ibu Uswatun Hasanah Kabag Technical Support BMT Al Hijrah KAN Jabung.

"Untuk Withholding tax system sendiri jujur saya tidak paham. Tapi kalau pemotongan/pemungutan pajak atas bagi hasil saya menerapkan di BMT ini, aya memotong pajak bagi hasil bagi koperasi sebesar 10\% sesuai peraturan dimana yang bagi hasilnya lebih besar samadengan Rp. 240.000. “

Dari hasil wawancara tersebut, jelas bahwa BMT Al Hijrah KAN Jabung telah melakukan sistem pemungutan pajak bagi hasil dengan withholding tax system. BMT Al Hijrah KAN Jabung melakukan withholding tax system pada beberapa jenis produk Baitul Tamwil dibagian penerimaan dana berupa simpanan dan mudharabah berjangka (deposito).

\section{Perhitugan Pajak Bagi Hasil}

Perhitungan Pajak Bagi Hasil Mudharabah Berjangka (Deposito) di BMT Al Hijrah KAN Jabung

\begin{tabular}{|c|c|c|c|c|c|c|}
\hline \multirow[t]{2}{*}{ NO } & \multirow{2}{*}{$\begin{array}{l}\text { NAMA } \\
\text { MATRAYIS TR } \\
\text { DKK }\end{array}$} & \multirow{2}{*}{ 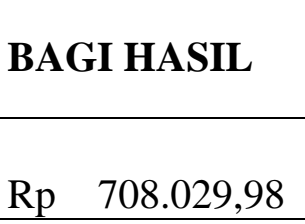 } & \multicolumn{2}{|c|}{ PAJAK } & \multicolumn{2}{|c|}{$\begin{array}{l}\text { BAGI HASIL YANG } \\
\text { DIBAYARKAN }\end{array}$} \\
\hline & & & $\mathrm{Rp}$ & $70.803,00$ & $\mathrm{Rp}$ & $637.226,98$ \\
\hline 2 & ST AMINAH HJ & $\mathrm{Rp} 1.180 .049,96$ & $\mathrm{Rp}$ & $118.005,00$ & $\mathrm{Rp}$ & $1.062 .044,96$ \\
\hline 3 & SUKI ANGG F & $\mathrm{Rp} \quad 459.955,09$ & $\mathrm{Rp}$ & $45.995,51$ & $\mathrm{Rp}$ & $413.959,58$ \\
\hline 4 & NUR MASLAKHAH & $\mathrm{Rp} \quad 188.805,01$ & $\mathrm{Rp}$ & - & $\mathrm{Rp}$ & $188.805,01$ \\
\hline 5 & $\begin{array}{l}\text { KHOIROTUL } \\
\text { ADAWIYAH }\end{array}$ & Rp $\quad 379.809,99$ & $\mathrm{Rp}$ & $37.981,00$ & $\mathrm{Rp}$ & $341.828,99$ \\
\hline
\end{tabular}

Sumber : BMT Al Hijrah KAN Jabung, Olahan 
Pajak bagi hasil = bagi hasil $\mathrm{X} 10 \%$

$$
\begin{aligned}
& =\operatorname{Rp} 708.029,98 \times 10 \% \\
& =\mathbf{R p} 7 \mathbf{7 0 . 8 0 3 , 0 0}
\end{aligned}
$$

Pajak bagi hasil = bagi hasil $\mathrm{X} 10 \%$

$$
\begin{aligned}
& =\operatorname{Rp} 1.180 .049,96 \times 10 \% \\
& =\operatorname{Rp~118.005,00}
\end{aligned}
$$

Pajak bagi hasil = bagi hasil $\mathrm{X} 10 \%$

$$
\begin{aligned}
& =\operatorname{Rp} \quad 459.955,09 \times 10 \% \\
& =\operatorname{Rp} 45.995,51
\end{aligned}
$$

Pajak bagi hasil = bagi hasil $\mathrm{X} 10 \%$

$$
\begin{aligned}
& =\operatorname{Rp} \quad 188.805,01 \times 10 \% \\
& =\mathbf{R p}-
\end{aligned}
$$

\begin{tabular}{|c|c|c|c|c|c|c|c|c|}
\hline NO & JENIS & NAMA & \multicolumn{2}{|c|}{ BAGI HASIL } & \multicolumn{2}{|c|}{ РАЈАК } & \multicolumn{2}{|c|}{$\begin{array}{c}\text { BAGI HASIL } \\
\text { YANG } \\
\text { DIBAYARKAN }\end{array}$} \\
\hline 1 & SAKINAH & $\begin{array}{l}\text { GUNAWAN } \\
\text { TR DBK }\end{array}$ & $\mathrm{Rp}$ & $421.278,96$ & $\mathrm{Rp}$ & 7,90 & $\mathrm{Rp}$ & $279.151,06$ \\
\hline 2 & ARAFAH & $\begin{array}{l}\text { DINA } \\
\text { FITRIATUL K }\end{array}$ & $\mathrm{Rp}$ & $1.347,77$ & $\mathrm{Rp}$ & - & $\mathrm{Rp}$ & $1.347,77$ \\
\hline 3 & HARI TUA & $\begin{array}{l}\text { MIRSA } \\
\text { MUBAROK }\end{array}$ & $\mathrm{Rp}$ & $1.037,25$ & $\mathrm{Rp}$ & - & $\mathrm{Rp}$ & $1.037,25$ \\
\hline 4 & NAJJAH & $\begin{array}{l}\text { YULISTIANA } \\
\text { KAN }\end{array}$ & $\mathrm{Rp}$ & $4.660,98$ & $\mathrm{Rp}$ & - & $\mathrm{Rp}$ & $4.660,98$ \\
\hline 5 & TARBIYAH & $\begin{array}{l}\text { NANANG } \\
\text { WIBOWO }\end{array}$ & $\mathrm{Rp}$ & $14.198,47$ & $\mathrm{Rp}$ & - & $\mathrm{Rp}$ & $14.198,47$ \\
\hline
\end{tabular}

Pajak bagi hasil = bagi hasil $\mathrm{X} 10 \%$

$$
\begin{aligned}
& =\operatorname{Rp} 379.809,99 \times 10 \% \\
& =\mathbf{R p} 37.981,00
\end{aligned}
$$

Berikut adalah beberapa sample dari pemotongan pajak bagi hasil yang dilakukan BMT Al Hijrah KAN Jabung dari setiap produk yang dikenakan pajak bagi hasil.

Tabel 2. Perhitungan Pemotongan Pajak Bagi Hasil Simpanan di BMT Al Hijrah KAN Jabung

Sumber : BMT Al Hijrah KAN Jabung, Olahan

Pajak bagi hasil = bagi hasil $\mathrm{X} 10 \%$

$$
\begin{aligned}
& =\operatorname{Rp} 1.421 .278,96 \times 10 \% \\
& =\operatorname{Rp~142.127,90}
\end{aligned}
$$

Pajak bagi hasil = bagi hasil $\mathrm{X} 10 \%$

$$
\begin{aligned}
& =\operatorname{Rp} 1.347,77 \text { X 10\% } \\
& =\mathbf{R p}-
\end{aligned}
$$

Pajak bagi hasil = bagi hasil $\mathrm{X} 10 \%$

$$
\begin{aligned}
& =\operatorname{Rp} 1.037,25 \times 10 \% \\
& =\mathbf{R p}-
\end{aligned}
$$


Pajak bagi hasil = bagi hasil $\mathrm{X} 10 \%$

$$
\begin{aligned}
& =\operatorname{Rp} 4.660,98 \times 10 \% \\
& =\mathbf{R p}-
\end{aligned}
$$

Pajak bagi hasil = bagi hasil $\mathrm{X} 10 \%$

$$
\begin{aligned}
& =\operatorname{Rp} 14.198,47 \text { X } 10 \% \\
& =\mathbf{R p}-
\end{aligned}
$$

Dari data bagi hasil atas simpanan dan mudharabah berjangka (deposito) diatas dapat dilihat bahwa jumlah bagi hasil yang kurang dari Rp 240.000,00 tidak dipotong pajak $10 \%$ dan untuk bagi hasil yang lebih dari Rp 240.000,00 dipotong pajak 10\%. Seperti halnya untuk simpanan at tarbiyah, an najah, ar rafah, dan simpanan hari tua tidak ada potongan pajaknya dikarenakan jumlah bagi hasil yang diterima oleh nasabah tidak mencapai Rp 240.000,00. Sedangkan untuk simpanan as sakinah dan mudharabah berjangka (deposito) dipungut pajak 10\% yang mana bagi hasil yang diterima lebih dari $\operatorname{Rp} 240.000,00$.

Dapat dilihat dari perhitungan bagi hasil simpanan as sakinah dengan nomor rekening 100-000012490-011 yang tidak dipotong pajak 10\% karena bagi hasil yang terima sejumlah Rp 76.273,22 yang mana nilai tersebut kurang dari Rp 240.000,00. Sedangkan bagi hasil dengan nomor rekening 100-000014299-011 dipotong pajak $10 \%$ karena jumlah bagi hasil yang diterima melebihi Rp 240.000,00 yaitu sebesar Rp 1.421.278,96 dengan potongan pajak sebesar Rp 142.127,90. Begitu pula dengan pemotongan pajak mudharabah berjangka (deposito), yang diterima oleh nasabah dengan nomor rekening 100-000012490-011 sebesar Rp 708.029,98 dikenakan pajak 10\% yaitu Rp 70.803,00 sedangkan nasabah dengan nomor rekening 100-000023905011 tidak dikenakan pajak 10\% karena bagi hasil yang diterimanya sebesar Rp $188.805,01$.

BMT Al Hijrah melakukan withholding tax system atas pajak bagi hasil ini, mengikuti standar ketentuan pajak atas bagi hasil SHU Koperasi yaitu 10\%. Hal ini desebabkan BMT adalah unit usaha yang berbadan hukum koperasi. Sesuai dengan ketetuan dalam Peraturan Menteri Keuangan Nomor 111/PMK.03/2010 yang membahas tentang pajak SHU koperasi 10\%. BMT yang merupakan lembaga keuangan syariah tidak diatur jelas dalam ketentuan perpajakan. Akan tetapi dalam Peraturan Menkeu Nomor 136/PMK.03/2011 dan Peraturan Pemerintah Nomor 25 Tahun 2009 pasal 4 menerangkan bahwa peraturan perpajakan atas lembaga keuangan syariah berlaku mutatis mutandis ketentuan dalam Undang-Undang Nomor 36 Tahun 2008 (UU PPh). Sedangkan dalam ketentuan koperasi diatur dalam Peraturan Menteri Keuangan Nomor 111/PMK.03/2010. Dalam hal ini BMT Al Hijrah yang merupakan salah satu lembaga keuangan syariah dan merupakan unit usaha berbadan hukum koperasi telah mengikuti peraturan perpajakan yang berlaku umum. 
Perhitungan pajak atas bagi hasil bagi koperasi sesuai dengan Peraturan Menteri Keuangan Nomor 111/PMK.03/2010 menerangkan bahwa pemotongan pajak atas penghasilan berupa deviden yang diterima atau diperoleh Wajib Pajak orang pribadi dalam negeri dikenai Pajak Penghasilan sebesar 10\% (sepuluh persen) dari jumlah bruto bersifat final. BMT Al Hijrah KAN Jabung yang merupakan badan hukum koperasi, sehingga harus menerapkan sistem pemotongan pajak bagi hasil atas simpanan dan deposito senesar $10 \%$ (sepuluh persen) bagi penerima bagi hasil lebih dari samadengan Rp 240.000,00. Hal ini dilakukan oleh BMT Al Hijrah sesuai dengan Peraturan Menteri Keuangan Nomor 112/PMK.03/2010 yang menerangkan tentang tata cara pemotongan, penyetoran, dan pelaporan pajak penghasilan atas bunga simpanan yang dibayarkan oleh koperasi kepada anggota koperasi orang pribadi. Terlihat dari perhitungan diatas, menunjukkan bahwa perhitungan pajak atas bagi hasil BMT Al Hijrah KAN Jabung yang bagi hasilnya lebih dari samadengan Rp 240.000,- dikenakan pajak $10 \%$ dari bagimhasil yang diterima. Sepertinya halnya bagi hasil atas mudharabah berjangka (deposito) atas nama St Aminah dengan nomor rekening 100-000005150-011dan bagi hasil dari tabungan atas nama gunawan dengan nomor rekening 100-000014299-011 dikenakan pajak pagi hasil 10\% karena bagi hasil yang diterima lebih dari samadengan Rp 240.000 yaitu sebesar Rp 1.180.049,96 dengan pengenakan pajak Rp 118.005,00 dan Rp 1.421.278,96 dengan pengenakan pajak Rp 142.127,90. Sedangkan untuk bagi hasil yang nilainya kurang dari Rp 240.000 tidak dikenakan pajak 10\% seperti halnya pajak atas mudharabah berjangka atas nama Nur Maslakhah dengan nomor rekening 100-000023905-011 dan bagi hasil dari simpanan atas nama Dina Fitriatul K dengan nomor rekening 100-000023418013tidak dikenakan pajak bagi hasil sebesar 10\% karena bagi hasil yang diterimanya kurang dari Rp 240.000. Dapat disimpulkan bahwa BMT Al Hijrah KAN Jabung telah melakukan sistem pemotongan pajak bagi hasil sesuai prosedur dengan mengacu Peraturan Menteri Keuangan Nomor 112/PMK.03/2010. Hal ini diperkuat jelas dari pernyataan hasil wawancara dengan ibu Uswatun Hasanah selaku Kabag Technical Support BMT Al Hijrah KAN Jabung, menjelaskan bagaimana prosedur pemotongan pajak bagi hasil:

"Untuk prosedurnya, yang mana bagi hasil lebih dari samadengan Rp. 240.000 secara otomatis akan dipotong pajak $10 \%$ dari hasil yang dibagikan, dan akan di sharekan di buku tabungan setiapa akhir bulan ke pihak yang dipotong”.

Dari pernyataan tersebut bahwa BMT Al Hijrah melakukan pemotongan bagi hasil atas simpanan dan mudharabah berjangka (deposito) sebesar $10 \%$ dari hasil yang dibagikan kepada nasabah yang mana bagi hasil tersebut lebih dari samadengan Rp 240.000,00. Sedangkan bagi hasil yang nilainya kurang dari Rp 240.000,00 tidak 
dipotong pajak atas bagi hasil. Terdapat beberapa simpanan yang menjadi produk Dari BMT Al Hijrah ini, akan tetapi bagi hasil dari simpanan tersebut tidak semuanya terpotong pajak 10\% dikarena jumlah bagi hasil yang kurang dari Rp 240.000,00.

\section{Pandangan Islam Mengenai Mutatis Mutandis}

Peraturan perpajakan atas pajak ba gi hasil yang tidak diatur jelas dalam Undang-undang atas Pajak Penghasilan Nomor 36 tahun 2008, karena pada prinsipnya Undang-undang membahas masalah-masalah global. Masalah yang lebih terperinci, akan diatur dalam Peraturan Pemerintah dan Peraturan Menteri Keuangan yang mengatur khusus tentang masalah teersebut. Seperti halnya dalam islam, beberapa permasalahan dalam islam yang hukumnya tidak diatur jelas dalam Al Quran dan Al Hadist karena pertumbuhan masyarakat begitu cepat dan kompleks sehingga membutuhkan jawaban yang tepat untuk mengantisipasinya. Oleh karena itu, para ulama melakukan ijtihad (penalaran kreatif) terhadap permasalahanpermasalahan yang secara tegas tidak dijelaskan oleh nash. Para ulama melakukan ijtihad untuk menetapkan hukumnya dengan jalan qiyas (analogi) untuk mencari illat (sebab hukum) yang ada dalam permasalahan yang timbul dan menyesuaikannya dengan ketentuan yang terdapat di dalam nash. Allah menyatakan dalam firman-Nya QS. Al Ankabut:43 bahwa hanya dengan ilmu orang bisa memahami perempumaan yang diberi Allah kepada manusia.

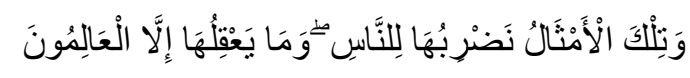

"Dan perumpamaan-perumpamaan ini Kami buat untuk manusia; dan tiada yang memahaminya kecuali orang-orang yang berilmu” (QS. Al Ankabut:43).

Dari penjelasan hukum islam diatas, jelas bahwa islam memperbolehkan sesuatu yang tidak ada nash-nya dalam ashal dengan cara mencarai persamaan illat hukumnya. Dalam hukum pajak penghasilan atas bagi hasil lembaga keuangan syariah yang tidsk diatur jelas dalam Undang-undang perpajakan nomor 36 tahun 2008 atas Pajak Penghasilan (PPh), sehingga hukum tersebut merujuk pada Peraturan Pemerintah Nomor 25 tahun 2009 serta Peraturan Menteri Keuangan Nomor 111/PMK.03/2010, 112/PMK.03/2010 dan 136/PMK.03/2011 yang mengatur jelas tentang tata cara, perhitungan, pelaporan dan penyetoran pajak bagi hasil atas lembaga keuangan syariah dan koperasi. Hal tersebut sesuai dengan siaran presiden pada tanggal 19 September 2011 mengenai pengenaan pajak penghasilan kegiatan usaha perbankan syariah yang berlaku mutatis mutandis ketentuan dalam Undangundang Nomor 7 tahun 1983 tentang Pajak Penghaslan sebagaimana telah beberapa kali diubah terakhir dengan Undang-undang Nomor 36 tahun 2008 (UU PPh). Maksud dari mutatis mutandis adalah ketentuan-ketentuan mengenai penghasilan, 
biaya, dan pemotongan pajak atau pemungutan pajak yang berlaku dalam UU PPh berlaku pula di Peraturan Menteri Keuangan dimaksud.

\section{SIMPULAN DAN SARAN}

\section{Simpulan}

1. Withholding tax system yang merupakan suatu sistem pemungutan pajak yang sangat membantu pemerintah dalam mencapai target pajak. Dalam sistem ini, pemungutan pajak dilakukan oleh pihak ketiga (bukan fiskus dan bukan Wajib Pajak yang bersangkutan) untuk memotong atau memungut pajak yang terutang oelh Wajib Pajak.

2. Penerapan withholding tax system secara teori belum sepenuhnya dikuasai oleh pelaku kegiatan, akan tetapi secara keseluruhan, BMT Al Hijrah KAN Jabung telah menerapkan withholding tax system sesuai peraturan yang berlaku.

3. Dari analisis dan pembahasan hasil penelitian maka dapat dibuat kesimpulan bahwa withholding tax system pada BMT Al Hijrah KAN Jabung terdapat pada bagi hasil simpanan dan mudharabah berjangka (deposito) yang secara keseluruhan perhitungannya telah sesuai dengan peraturan peraturan yang berlaku pada BMT dan koperasi.

4. Perhitungan atas simpanan dan bagi hasil pada BMT Al Hijrah KAN Jabung lebih menggunakan istilah bagi hasil yang mana bagi hasil tersebut akan diberikan kepada nasabah sesuai dengan kesepakatan antara nasabah dan BMT pada awal perjanjian.

5. Bagi hasil yang merupakan salah satu objek pajak seperti bunga pada lembaga keuangan konvensional dikenakan pajak 20\%. Sedangkan BMT Al Hijrah KAN Jabung yang merupakan salah satu lembaga yang berbadan hukum koperasi dikenakan pajak sebesar 10\% sesuai dengan Peraturan Menteri Keuangan Nomor 111/PMK.03/2010 yang membahas tentang pajak SHU koperasi 10\%.

6. Mekanisme pemotongan pajak bagi hasil dilakukan pada saat Wajib Pajak (nasabah) yang menerima bagi hasil lebih dari sama dengan Rp. 240.000,sebesar $10 \%$.

\section{Saran}

Bagi peneliti Selanjutnya

a. Data yang digunakan peneliti hanya terbatas data atas simpanan dan mudharabah berjangka (deposito). Sehingga masih adanya kurang data pendukung yang digunakan sebagai pembanding. Peneliti selanjutnya sebaiknya menggunakan data yang lebih lengkap dibandigkan penelitian sekarang. 
b. Buku pedoman yang digunakan dalam penelitian ini hanya terbatas dengan perpajakan konvensional, sehingga perlu adanya tambahan reverensi dari buku yang lebih luas secara syariah.

c. Metode yang digunakan peneliti sangat sederhana, sehingga perlu adanya metode lain yang lebih baik agar data yang dianalisis lebih akurat.

Bagi Perusahaan

Ketidaktahuan karyawan akan withholding tax system dapat menjadikan kesalahpahaman antara karyawan dan Wajib Pajak (nasabah) dalam hal pemotongan pajak, sehingga perlunya pemahaman mengennai withholding tax system terhadap karyawan khususnya di bagian castemer service. 


\section{DAFTAR PUSTAKA}

Al-Hadits dan terjemahan

Al-Qur'an al-Karim dan terjemahan.

Annisa, Nur. (2016). Implementasi Sistem Withholding Tax Terhadap Pajak Penghasilan (PPh) pada Bank Muamalat Indonesia KCP Tulungagung dan Bank Jatim Cabang Syariah Kediri, Skripsi (dipublikasikan). Jurusan Ekonomi Syariah Institut Agama Negeri, Tulungagung.

Anshori, Abdul Ghofur. (2009). Perbankan Syariah di Indonesia. Yogyakarta: Gadjah Mada University Press

Ascarya. (2007). Akad \& Produk Bank Syariah. Jakarta: Gaja Grafindo persada

Azizah, Nurul. (2015). Faktor - Faktor Yang Mempengaruhi Realisasi PembiayaanMudharabah dan Murabahah di BMT Sahara Tulungagung,. Skripsi (dipublikasikan). Jurusan Ekonomi Syariah Institut Agama Negeri, Tulungagung.

Beni Ahmad., Januri. (2014). Ushul Fiqh. Bandung: Pustaka Setia.

Cokrohadisumarto, Widiyanto bin Ismail., Ismail, Abdul Ghafar., Wibowo, Kartiko A. BMT Praktek dan Kasus. (2016). Jakarta: Rajawali Pres.

Erlinda, Desiana Sagita. (2011). Analisis Perhitungan, Penyetoran, dan Pelaporan Withhoding Tax pada Bank BTN Syariah Malang,Skripsi (dipublikasikan). Jurusan Akuntansi Politeknik Negeri, Malang.

Fauzan, M. (2014). Kaidah Penentuan Hukum Yurisprudensi Bidang Hukum Perdata. Jakarta: Prenadamedia Group

Ibrahim, Qasim a., Saleh, Muhammad A. (2014). Buku pintar sejarah islam. Jakarta: serambi ilmu semesta.

Kementrian Keuangan Republik Indonesia. (2017). APBN 2017. Jakarta. Diperoleh tanggal 3 November 2017dari https://www.kemenkeu.go.id/apbn2017

Mardiasmo. (2016). Perpajakan (revisi). Yogjakarta: Andi Offset.

Mokoagow, Wita Wardani. (2015). Analisis Perhitungan Pph Pasal 4 Ayat 2 atas Bunga Deposito dan Tabungan Nasabah pada PT. Bank Sulut Cabang Kota Mobagu. Jurnal EMBA, Vol.3 No.3. 807-816. 
Moleong, Lexy J. (2014). Metodologi Penelitian Kualitatif. Bandung:PT. Remaja Rosdakarya.

Resmi, Siti. (2017). Perpajakan (Edisi 10). Jakarta: Salemba Empat.

Sugiyono. 2012. Metode Peneltian Kombinasi. Bandung : Alfabetha.

Tangka, Iraine Sari., Sabijono, Harijanto. (2014). Analisis Perhitungan PPh Final Pasal 4 Ayat 2 atas Bunga Deposito dan Tabungan Nasabah pada PT. Bank Rakyat Indonesia (Persero), Tbk Cabang Manado. Jurnal EMBA 203, Vol.2 No.4. 203-213.

Watung, Leonardo Romario. (2016). Analisis Penerapan Pajak dengan Withholding Tax System Terhadap Pajak Penghasilan Pasal 4 Ayat 2 pada PT. Bank Sulutgo di Kota Manado. Jurnal EMBA Vol.4 No.1 Maret 2016, Hal. 916-923.

Wiroso. (2011). Akuntansi Transaksi Syariah. Jakarta: Ikatan Akuntansi Indonesia.

Yurizkanti, Aghnia., Sasongko, Catur. (2013). AnalisisKetepatan Pengenaan PPh untuk Deposito Mudharabah yang Dipersamakan dengan Deposito Bank Konvensional. FE UI

\section{SAK ETAP}

UU Nomor 36 Tahun 2008Tentang Pajak Bagi hasil

Peraturan Pemerintah Nomor 25 Tahun 2009Pajak Penghasilan dari kegiatan usaha berbasis syariah

Peraturan Menteri Keuangan Nomor 136/PMK.03/2011 Tentang Pajak Penghasilan untuk kegiatan usaha pembiayaan syariah

Peraturan Menteri Keuangan Nomor 112/PMK.03/2010Tata cara pemotongan, penyetoran, dan pelaporan pajak penghasilan atas bunga simpanan yang dibayarkan oleh koperasi kepad anggota koperasi orang pribadi

Peraturan Menteri Keuangan Nomor 111/PMK.03/2010 Tata cara pemotongan, penyetoran, dan pelaporan pajak penghasilan atas dividen yang diterima atau diperoleh wajib pajak orang pribadi dalam negeri

http://ejournal.unsrat.ac.id/index.php/emba/article/view/6239/5764, diakses 20 April 2015.

http://erlinresepkue.blogspot.com/2011/11/analisis-perhitungan-pemotongan dan.html, diakses tanggal 24 Mei 2014. 